UDC 821.113.4

\title{
Tatjana Pilipoveca
}

University of Tartu

\section{THE SNOW QUEEN IN THE ANTHOLOGY OF RUSSIAN ALIEN FAIRY TALES: AN OLD STORY IN A NEW WORLD}

Classical fairy tales exist in contemporary popular culture in different variants. They are quoted and reworked in TV shows, theatrical performances, video games, memes and different literary texts. The interest into old, well-known fairy tales is commonly explained by the omnipresent love of wonder and the eternal relevance of these stories. However, a careful study can reveal that contemporary adaptations question precisely the relevance of concrete canonical fables and the relevance of fairy tale as a phenomenon.

In this article we are going to analyze Russian interpretations of Hans Christian Andersen's story The Snow Queen in the anthology of Russian Alien Fairy Tales. The Snow Queen, first published by Hans Christian Andersen in 1844, which was initially translated into the Russian language in 1863. It has ever since remained one of the most cherished fairytale plots of the Russian audience. There are canonical interpretations of this Danish text in Russian poetry, cinematography and theater. Our interest lies on the contemporary short prose that belongs to popular culture and could be considered as a manifestation of the current literary process.

Keywords: Hans Christian Andersen, The Snow Queen, literary fairy tale, contemporary interpretations, popular culture, adaptation, retelling.

\section{Татьяна Пилиповец}

Тартуский университет

\section{"СНЕЖНАЯ КОРОЛЕВА" В АНТОЛОГИИ "РУССКИЕ ИНОРОДНЫЕ СКАЗКИ": СТАРАЯ ИСТОРИЯ В НОВОМ МИРЕ}

Современная популярная культура постоянно пересказывает и интерпретирует канонические сказки. Они существуют в виде фильмов, художественных проектов, видеоигр и литературных текстов различных жанров. Трансмедийное пересказывание порождает бесконечное количество вариантов классической истории. Благодаря этому процессу сказка может реагировать на изменяющийся культурный контекст.

Непропадающий интерес к старым, хорошо известным литературным сказкам часто объясняется любовью аудитории к чуду и вечной актуальностью этих историй. Однако более тщательное исследование показывает, что современные интерпретации сказок оспаривают идеи, заложенные в оригинальных текстах. 
В статье мы анализируем десять интерпретаций сказки Г.Х.Андерсена «Снежная королева» из "Антологии русских инородных сказок», составленной литературным проектом Макс Фрай. «Снежная королева» - один из наиболее любимых русской аудиторией сказочных сюжетов. По мотивам этой сказки было создано несколько канонических русских интерпретаций. В сказке поднимаются проблемы, которые вызвали живую дискуссию и среди современных авторов. В статье мы постараемся ответить на следующие вопросы: как, почему и для кого современные авторы перерабатывают датскую сказку? Считают ли они актуальными идеи ее автора?

Ключевые слова: Ганс Кристиан Андерсен, Снежная королева, литературная сказка, современные интерпретации, популярная культура, пересказывания.

Russian Alien Fairy Tales («Русские инородные сказки») is an anthology of modern fairy tales created by the literary project Max Frei ${ }^{1}$ in cooperation with the publishing house Amfora. The anthology consists of eight volumes. The first was published in 2003, the final one - in 2010. The main goal of creating this anthology was not to choose best texts or affirm any version of literary pantheon; it was rather to show what is going on in the contemporary literary field, in other words, to create a representative sample. Russian Alien Fairy Tales consist of collated texts by Russian-writing authors of different backgrounds, levels of popularity, professionalism, success and talent [Лебедушкина, 2007]. However, according to Max Frei, he has found two-thirds of all anthology texts in such internet platforms as, for instance, Life Journal [Макс Фрай, 2003]. Therefore, to a significant extent the anthology represents fairy tales on Internet sources covering a period of seven years during which the volumes were published. In one of the interviews, Max Frei said he wanted the audience to have access to modern texts that he considered worth reading, - thus not attempting to conceal the fact that the choice of texts for anthologies was based on his personal taste [Макс Фрай, 2003].

1 Svetlana Martynchik started the literary project Max Frei in co-authorship with the artist Igor Stepin in the second part of 1990's. Max Frei appeared in the field of Russian literature as simultaneously the author, the main character, and the narrator of the the series of books called Labyrinths of Echo (цикл «Лабиринты Эхо»). Nowadays Max Frei is the whole complex of different projects unified by common brand. In one of interviews Martynchik said that she plays in literary games under the same name on different platforms [Макс Фрай, 2003]. There is Max Frei, who is the popular writer of many books; Max Frei, who is the literary character; Max Frei, who is the professional critic and the columnist; as well as Max Frei - the reader, who shares his subjective tastes with other readers by creating anthologies. 
In all eight volumes of Russian Alien Fairy Tales one can find short annotations that explain the main idea behind the anthology and Max Frei's personal attitude towards the work. The basic ideas rendered in these annotations may be summarized in a few sentences as follows: 1. The genre of the literary fairy tale is alive. 2. Both young unknown authors and more recognizable ones continue to turn to the genre and develop it. 3. The genre has undergone a transformation: all fairy tales in the anthology are written for adults.

The anthology includes fairy tales with original author's plots and texts that appeal to classical tales in various ways. In the book The Irresistible Fairy Tale, 2012 Jack Zipes distinguished two tendencies describing the ways in which motives of classical tales can be used in contemporary visual art. These tendencies - remaking and creation of conflicted mosaics - are clearly present in the literary field as well. Remaking presupposes deconstruction of the well-known story with the intention to criticize and question its main ideas and images. Numerous remakes of well-known fairy tales can be found in various internet-platforms for the fanfiction. Fanfics are secondary texts that are overtly connected to other texts significant for popular culture. Fanfiction writers usually offer their own versions of stories: they offer alternative endings, re-use and develop images of characters, create sequels and prequels. In conflicted mosaics authors do not rethink concrete narratives, but rather use some recognizable signs of canonic fairy tales in order "to evoke a sense of wonder, if not bafflement" [Zipes, 2012, p. 137] Texts of both types are present in the anthology of Russian Alien Fairy Tales.

In the context of classical tales that are rethought, reworked and quoted by the authors of the anthology, Hans Christian Andersen's stories have a significant role. In eight volumes we have found 23 texts where motives of different tales by H.C. Andersen were used. Among them are The Princess on the Pea, 1835; Thumbelina, 1835; The Little Mermaid, 1837; The Wild Swans, 1938; Ole Lukoie, 1841; The Swineherd, 1841; The Ugly Duckling, 1843; The Little Match Girl, 1845; Clumsy Hans, 1855. However, the most widely used fairy tale by H.C.Andersen in Russian Alien Fairy Tales is The Snow Queen, 1844. Motives from The Snow Queen are distinctly present in 10 texts of the anthology. Five of these texts may be considered as conflicted mosaics; the other five - as remakes. 
All together in the anthology are collected texts by 127 authors: 65 of them are female authors; 53 are male; nine use pseudonyms that don't allow to determine the sex of the author. Out of all the authors who used The Snow Queen for creating conflicted mosaics three are male and two are female. Out of all the authors who created remakes based on this famous tale by the Great Dane four are female, and only one is male.

In conflicted mosaics the authors of the anthology used easily recognizable features from The Snow Queen with the intention to add some additional fairytale dimension into their own texts. For instance, in the fairy tale called Evening Sermon the main character freezes and thinks that only The Snow Queen could enjoy such a cold weather [Макс Фрай, 2003] In the text To Run in the Sudden Fog the main character meets a lady in the street who reminds him of The Old Robber Woman [Хаецкая, 2008]. In the third volume of the anthology, we may find The Tale About the Princess Who Didn't Know How to Choose for Herself a Suitable Fairy Tale. In this text by Gala Rubinstein The Princess has to choose the fairy tale in which she will act as the main character. She can become The New Princess on the Pea, The New Sleeping Beauty, or even The New Snow Queen. All the tales terrify the Princess as ordeals; however, The Snow Queen is one of the worst [Рубинштейн, 2005]. The Snow Queen's kingdom as the paradise for the broken fridge is mentioned in the fairy tale Funerals of The Refrigerator [Аксенов, 2003].

The most interesting case of the conflicted mosaic can be seen in the fairy tale The Princess and The Dragon by Sergei Krasikov. This fairy tale is about a Jewish girl Rachel, who is taken to the concentration camp with her grandfather and her toy-dragon Kai. Rachel named her dragon Kai after the character from the fairytale The Snow Queen that her mother used to tell her, when she was alive. Rachel's mother also used to call Rachel for "princess". The girl hopes that her dragon Kai would save her, as Gerda saved her brother in H.C. Andersen's story. She believes that Kai will take her to a happy world, where her mother comes to visit. Krasikov's fairy tale ends when the dragon finally takes Rachel to the wonderland; however, the attentive reader understands that the girl entered into the gas chamber [Красиков, 2003].

The fairytale dimension in Krasikov's text has the potential of a shelter for the main character. The author of The Princess and The Dragon uses utopian features of classical literary fairytales: the dragon Kai 
obviously belongs to the world where every story has a happy ending. In Krassikov's interpretation the wonderland becomes even more utopian, as all dragons are good there, and Kai comes to the rescue. In the real world, where Rachel has no chances for survival, the dragon Kai represents the wonder itself.

All the authors of the remakes interpret H.C. Andersen's story mainly through the perspective of love conflict. In the sequel Christmas Fairy Tale the Snow Queen waits for Kai to come back and stay for 100 years. Her dream comes true; Kai appears in the ice castle with the marriage proposal as The Father Frost [Лукас, 2008]. In Gala Rubinstein's fairy tale How to Make a Man Happy. Guidelines for Girls Gerda is obsessed with the idea of Kai's happiness, but refuses to have any sexual relationship with him. Kai meets an unknown girl in the forest and leaves Gerda for her. Desperate, Gerda enters a relationship with The Little Robber Girl. In the end of the fairy tale, Kai and Gerda reconcile and begin having sexual relations. However, in the moments of intimacy Gerda usually imagines the The Little Robber Girl [Pyбинштейн, 2006]. In The Snow Fairy Tale by Olga Lukas Gerda falls in love with The Snow Queen, who helps Kai to create a perpetual motion machine that will work only on the ice. (Лукас 2008) In the text Fairy Tales for Me Gerda never reaches the castle of The Snow Queen, but stays instead with the Little Robber Girl who gets a surgery and becomes The Big Robber. Together they travel around the world. At that time Kai rescues himself and becomes rich. He changes his name, finds Gerda, takes her away from The Big Robber, and they get married. Gerda does not recognize Kai and for the rest of her life thinks that she is living with the some other man [Санжарова, 2008]. The only male exception amongst the prevailingly female interpreters of The Snow Queen is Ivan Matveev, who wrote a text called Eternal. However, Matveev's interpretation also involves the subject gender issues. He transforms the motive of Kai's task to make the word "eternity" from icicles into the Tetris game [Матвеев 2009]. The "eternal" conflict in Matveev's fairy tale is a quarrel between Kai, who represents all men and likes to play computer games, and Gerda, who represents all women and dislikes men playing computer games.

In all the texts that were examined the fairy tale is juxtaposed to the reality. In the case of the conflicted mosaics, the tale, on the one hand, 
is contrasted with the mundane life and, on the other, complements it. The reference to The Snow Queen implies the reference to the fairy tale as the phenomenon. In the case of remakes, The Snow Queen is opposed to the real life more as the concrete text. An important aspect of the contemporary remaking of the Danish tale is the subversion of traditional morals and values that H.C. Andersen's text transmits. According to Jack Zipes, the literary fairy tale had the "civilizing mission" as its function from the very moment, when the genre was born ${ }^{2}$ [Zipes, 2006, p.3]. In his fairy stories Hans Christian Andersen overtly proclaimed Christian and bourgeois ideas about the "good" human and his/ her behavior in the society. Andersen had a tendency to "use girls as examples in Christian allegorical fairy tales" [Zipes, 2007, p. 123]. He put his female characters on the path of ordeals and redemption: little Gerda traveled through half of the world to the North alone, barefoot and without worm clothes. Whether because of patriarchal ideas of his time or because of a personal inclination, "Andersen insisted that they $<$ female characters $>$ become self-sacrificial and pious. It was not much different for the male characters in Andersen's tales, but interestingly, he did not treat male characters as harshly as he did girls" [Zipes, 2007, p. 124]. The reality has changed since Andersen's times; his fairy tale in its canonical version stayed the same. Although The Snow Queen was constantly recreated in Russian culture in different artistic forms; the cartoon The Snow Queen from 1957 directed by Lev Atamanov may be considered as the most powerful Russian adaptation. The latter is the adaptation that demonstrates highest fidelity to the original text. However, in this cartoon are absent the significant religious motives - that is, the image of The Devil/ The Evil Troll, psalms and other references to the Bible. Even if religious subtext was crucial for Andersen, without it the story functions almost in the same way: it transmits the same values and morals ${ }^{3}$. It is possible to say that Atamanov's cartoon plays a similar role for The Snow Queen reception in Russian culture, as Walt Disney

2 "Almost all critics who have studied the emergence of the literary fairy tale in Europe agree that educated writers purposely appropriated the oral folktale and converted it into a type of literary discourse about mores, values, and manners so that children and adults would become civilized according to the social code of that time» [Zipes, 2006, p.3].

3 It is important to notice that religious motives are also absent in all the analyzed remakes: none of the authors paid attention to the Christian component of Andersen's text. 
Company cartoons do for the reception of such classic tales as The Snow White, The Sleeping Beauty or The Little Mermaid in Western European culture. These cartoons are highly conservative and become canonical not only as fairy tale films, but as fairy tales in general.

As we already mentioned, the biggest part of remakes in the anthology are written by female authors. They don't agree with the roles prescribed to them in Andersen's fairy tale. Contemporary culture that is strongly influenced by postmodern and feminist tendencies reacts to traditional ideas of Andersen's text: Why should Kai stay with Gerda? Why should Gerda be obsessed with Kai's happiness? Why should The Snow Queen be the evil power? Finally, why can't Gerda fall in love with the Snow Queen or the Little Robber Girl?

In one way or the other, remakes of The Snow Queen challenge original Andersen's ideas and restructure the narrative of the famous Danish story. It seems that the authors have an intention of bringing fairy tales closer to real life. They psychologize characters by making them less symbolic, more ambiguous and similar to real people. Characters' choices become less obvious and sometimes contradict the whole idea of the fairy tale as a genre. Authors mostly avoid the distinction between "good" and "bad" and try to imply in their texts that human relations are complicated, an idea uncommon for the classic literary fairy tale. They speak ironically about the image of self-sacrificing Gerda. There are no remakes in the anthology where The Snow Queen appears as an evil character. Contemporary culture cannot accept the simplified idea of "goodness" offered in traditional tales.

It seems that the authors of Russian Alien Fairy Tales anthology challenge not only the idea of what is "right behavior", but also the idea of a happy ending and of happiness as such. It is important to notice that there are no bad endings in remakes, only different happy endings, alien to the classical tradition. Despite all attempts to subvert the image of the classical fairy tale, new fairy tales preserve therapeutic and miraculous functions at least to certain extent.

However, we should point out that the intention to challenge the conservative ideas transmitted by The Snow Queen story is not the only possible explanation of the ways how it is interpreted in remakes collected by Max Frei. Andersen's tale is a multilayered, complicated artistic work that comprises different conscious and unconscious implications. In the article “The Snow Queen”: Queer Coding in Male Directors' 
Films Pauline Greenhill writes about the process of reading Andersen's oeuvre through the prism of his personality, in particular, through the homosexual aspect [Greenhill, 2015, p. 110-134]. In three remakes of the anthology it is possible to recognize motives of homosexual love between characters. This interpretation could be also understood as the recognition and decoding of elements already present under disguise in Andersen's text. However, even if the authors of the anthology have the intention to uncover unconscious implications in The Snow Queen, they still subvert the traditional reading and the "sanitized" image of the text in culture.

The biggest part of literary fairy tales, including stories by H.C.Andersen, is texts with the double addressee. They are intended both for children and adults at the same time. However, as Max Frei mentioned in one of the annotations, in Russian Aliens Fairy Tales new tales and retellings of the old stories are meant only for adults. In this aspect, the fairy tales from the anthology point back at the predecessor of the literary fairy tale - that is, at the folktale.

Another important aspect revived is variability. Variability is one of the most interesting features of the fairy tale phenomenon. It was also crucial for the folktale, but became restrained and less obvious when the fairy tale transformed into the literary genre. After this, the process of canonization of particular versions of the stories began.

The anthology of Max Frei belongs to the general transmedial retelling of fairy tales in the contemporary culture. Retelling generates numerous variations of classic literary fairy tales and places the fairy tale phenomenon in a position where it regains the possibility to react to the changing reality. Every new interpretation - commercial or amateur reflects simultaneously the author's personal ideas as well as the ideas of his/her time.

The fact that contemporary authors still apply The Snow Queen fairy tale indicates that this text addresses issues that are still relevant and widespread in the contemporary world. However, the solutions offered in the story raise a lively discussion among contemporary authors.

In order to be retold, any text should have something that is necessary to preserve and something that is necessary to challenge. Creation of remakes and conflicted mosaics provides the authors with the possibility to do both. On the one hand, every new text changes the fairy tale; on the other hand, it strengthens the position of the canonical version in 
the culture. To truly appreciate remakes or conflicted mosaics the reader should know the original.

\section{REFERENCES}

Aksenov R. Pokhorony kholodil'nika [Funerals of The Refrigerator]. Russkie inorodnye skazki [Russian Alien Fairy Tales]. Moscow, AMFORA Publ., 2003. Available at: http://www.e-reading.club/chapter.php/60594/7/Fraii_-_Russkie_inorodnye_skazki_1.html (accessed: 23.02.2017). (In Russian)

Frai M. Vecherniaia propoved' [Evening Sermon]. Russkie inorodnye skazki [Russian Alien Fairy Tales]. Moscow, AMFORA Publ., 2003. Available at: http:// www.e-reading.club/chapter.php/60594/66/Fraii_-_Russkie_inorodnye_skazki_1.html (accessed: 23.02.2017). (In Russian)

Frai M. Zhivoi Zhurnal slovami pisatelei [Live Journal through Words of Writers]. Russkii zhurnal [Russian Journal], 2003. Available at: http://old.russ.ru/ krug/20030627_mf.html (accessed: 23.02.2017). (In Russian)

Greenhill P. «The Snow Queen»: Queer Coding in Male Directors' Films. Marvels \& Tales, 29.1, 2015.

Khaetskaia E. Bezhat' sredi vnezapnogo tumana [To Run in the Sudden Fog]. Russkie inorodnye skazki 6 [Russian Alien Fairy Tales 6]. Moscow, AMFORA Publ., 2008. Available at: http://www.e-reading.club/chapter.php/126758/119/ Fraii_-_Russkie_inorodnye_skazki_6.html (accessed: 23.02.2017). (In Russian)

Krainer N. Rozhdestvenskaia skazka [Christmas Fairy Tale]. Russkie inorodnye skazki 3 [Russian Alien Fairy Tales 3]. Moscow, AMFORA Publ., 2005. Available at: http://www.e-reading.club/chapter.php/126194/188/Fraii_-_Russkie_ inorodnye_skazki_3.html (accessed: 23.02.2017). (In Russian)

Krasikov S. Printsessa i drakon [The Princess and The Dragon]. Russkie inorodnye skazki [Russian Alien Fairy Tales]. Moscow, AMFORA Publ., 2003. Available at: http://www.e-reading.club/chapter.php/60594/155/Fraii_-_Russkie_ inorodnye_skazki_1.html (accessed: 23.02.2017). (In Russian)

Lebedushkina O. Shekherezada zhiva, poka... [Scheherazade is Alive, For Now...]. Druzhba narodov [Friendship of Nations 3], 2007, no. 3. Available at: http://magazines.russ.ru/druzhba/2007/3/le12.html (accessed: 23.02.2017). (In Russian)

Lukas O. Snezhnaia skazka [The Snow Fairy Tale]. Russkie inorodnye skazki 6 [Russian Alien Fairy Tales 6]. Moscow, AMFORA Publ., 2008. Available at: http://www.e-reading.club/chapter.php/126758/165/Fraii_-_Russkie_inorodnye_skazki_6.html (accessed: 23.02.2017). (In Russian)

Markova D. Proekt avtomatom [Project Automatically]. Znamia, 2008, no. 10. Available at: http://magazines.russ.ru/znamia/2008/10/ma13.html (accessed: 23.02.2017). (In Russian)

Matveev I. Vechnoe [Eternal]. Russkie inorodnye skazki 7 [Russian Alien Fairy Tales 7]. Moscow, AMFORA Publ., 2009. Available at: http://www.e-reading. 
club/chapter.php/104646/174/Fraii_-_Russkie_inorodnye_skazki_7._Zhilibyli.html (accessed: 23.02.2017). (In Russian)

Rubinshtein G. Kak sdelat' muzhchinu schastlivym [How to Make a Man Happy.]. Rukovodstvo dlia devochek. Russkie inorodnye skazki 4 [Guidelines for Girls. Russian Alien Fairy Tales 4]. Moscow, AMFORA Publ., 2006. Available at: http://www.e-reading.club/chapter.php/126147/166/Fraii_-_Russkie_inorodnye_skazki_4.html (accessed: 23.02.2017). (In Russian)

Rubinshtein G. Skazka o printsesse, kotoraia nikak ne mogla vybrat' dlia sebia podkhodiashchuiu skazku [The Tale About the Princess, Who Didn't Know, How to Choose the Suitable Fairy Tale for Herself]. Russkie inorodnye skazki 3 [Russian Alien Fairy Tales 3]. Moscow, AMFORA Publ., 2005. Available at: http://www.e-reading.club/chapter.php/126194/228/Fraii_-_Russkie_inorodnye_skazki_3.html (accessed: 23.02.2017).(In Russian)

Sanzharova O. Skazki dlia menia [Fairy Tales for Me]. Russkie inorodnye skazki 6 [Russian Alien Fairy Tales 6]. Moscow, AMFORA Publ., 2008. Available at: http://www.e-reading.club/chapter.php/126758/187/Fraii_-_Russkie_inorodnye_skazki_6.html (accessed: 23.02.2017).

«Snezhnaia koroleva» [The Snow Queen]. Soiuzmul'tfil'm, Lev Atamanov, 1957. 1 pt. 34 min. 36 sek. (In Russian)

Zipes J. Fairy Tales and the Art of Subversion: The Classical Genre for Children and the Process of Civilization. New York, Routledge Publ., 2006

Zipes J. The Irresistible Fairy Tale: The Cultural and Social History of a Genre. Published by Princeton University Press. 2012

Zipes J. When Dreams Came True: Classical Fairy Tales and Their Tradition. New York, Routledge Publ., 2007.

\section{Tatjana Pilipoveca}

University of Tartu,

Ülikooli 18, 50090, Tartu, Estonia

E-mail: tatjana.pilipovec@gmail.com 